\title{
Divining the path to a successful European exit
}

\author{
Håkon Kirkeby Buch, Anna C Gustafsson, Viktor Drvota \& Carl Johan Sundberg \\ A gathering of biotech leaders in Sweden attempts to share candid opinions on the most successful strategies for \\ building a biotech in Europe.
}

A recent report in Harvard Business Review ${ }^{1}$ Adescribes the global venture capital industry as in a state of distress: delivering too little, too late to investors and, at the same time, losing dominance over its most valuable assetentrepreneurs and their innovations. The venture-backed life science industry, notoriously known for its sky-high development costs and heavy regulation, is no exception.

In this context, SEB Venture Capital and Karolinska Institutet gathered 80 industry leaders in March 2010 for a 'Life Science Exit Seminar-How to Promote and Exit Venture Backed Companies'. The seminar placed an emphasis on examining exits from European-based, venture-backed life science companies, which have become increasingly geographically disadvantaged by a US-dominated transaction market. The participants of the symposium included current and former CEOs, venture capitalists (VCs), advisors and representatives from multinational industrial buyers. In the following article, we summarize the main themes emerging from the meeting's discussions and best practices for building a European biotech business and achieving a successful exit.

\section{Straightforward exits are scarce}

At our seminar, the general question was posed, "At what development stage is it optimal to exit life science companies?" The text-book answer is that if your product can

Håkon Kirkeby Buch is an analyst,

Anna Gustafsson is an investment manager and Viktor Drvota is head of life science investments at SEB Venture Capital in Stockholm, Sweden. Carl Johan Sundberg leads the Unit for Bioentrepreneurship at Department of Learning, Informatics, Management and Ethics at Karolinska Institutet in Stockholm, Sweden. e-mail: carl.j.sundberg@ki.se

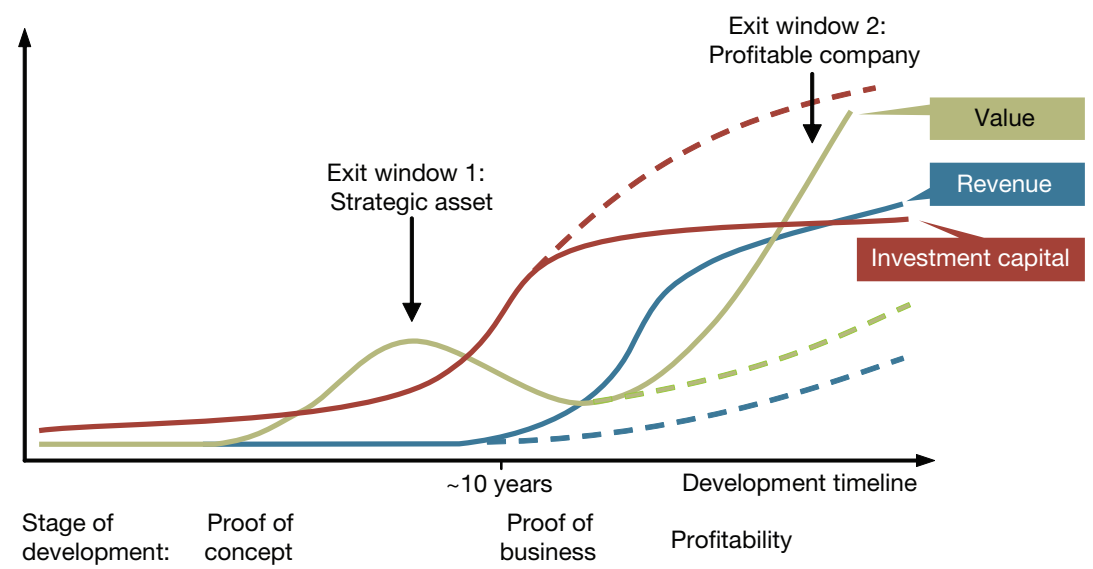

Figure 1 Exit windows in a company's life cycle. Exit window 1 is characterized by early acquisition of strategically important assets to a buyer. Exit window 2 is typically the revenuebased trade sale or public listing of a sustainable company. Venture-financed development from startup to the second exit window generally falls outside the scope of most venture capitalist mandates in the case of pharmaceuticals, except for orphan drugs. The dotted lines mean failure due to overspending and/or inability to become profitable.

transform a medical practice, someone will buy it for a lot of money before you have made one sale. Another typical answer, of course, is that if your company has scalable products turning over significant sales and bringing in sizable annual revenues, you will have no trouble finding a buyer and thus an exit. But such examples in the European biotech sector are scarce.

Although it is true that new products are always in demand, it is also true that big pharma and biotech buyers are more sophisticated than they once were. On top of that, regulatory requirements are driving up development costs in both biotech/pharma and medical technology. Also, buyers have become very astute in determining the cost base of targets and are especially mindful of how much money further development is going to cost. Recent data now suggest it takes, on average, more than 15 years and $\$ 1$ billion to develop a blockbuster drug through to regulatory approval ${ }^{2}$. Likewise, taking new medical technology products to market has become an exhausting exercise for both entrepreneurs and their investors.

Some speakers at the seminar thought that exits must come after developing the technology for just a few years, and that these exits are basically an early trade sale of a pre-revenue asset, a so-called 'tech sale.' If that route is not taken, then you must be willing to build a sustainable company, enabling a cash flow-based exit, which generally takes $15-20$ years.

In other words, in Europe and elsewhere, bringing new life science innovations all the way from the idea stage to sustainable, initial public offering (IPO)-ready companies funded on venture capital alone might take a long time and require substantial resources (Fig. 1).

Of course, not every successful exit will include all steps of the classic life science venture capital investment scheme, which is invest early, develop product(s), obtain regulatory approval, generate revenue growth, become 


\section{Table 1 Challenges and actions for venture capital syndicates}

Keeping consensus on exit strategy often proves difficult because the priorities of the various venture capital funds comprising your syndicate change over time. To head off problems in differing expectations of syndicate members, it may be necessary to take preemptive action. The types of different actions you should consider are listed.

\begin{tabular}{ll}
\hline Challenge & Actions \\
\hline $\begin{array}{ll}\text { Loss of business momentum } \\
\text { disagreements due to }\end{array}$ & $\begin{array}{l}\text { Leave owner discussions outside the company board room. } \\
\text { Ensure that board and management focus is placed on core } \\
\text { business, not investor agenda. } \\
\text { Evaluate board composition and replace members to better } \\
\text { reflect the new situation of the company. }\end{array}$ \\
$\begin{array}{ll}\text { Financial distress necessitating internal } \\
\text { down round with severe dilution of }\end{array}$ & $\begin{array}{l}\text { Mitigate pressure from the leaving investor that might force an } \\
\text { nonparticipating owners }\end{array}$ \\
& $\begin{array}{l}\text { Evaluate if a smaller investor base is sufficient to continue } \\
\text { operations and adjust business plan accordingly. }\end{array}$ \\
\hline
\end{tabular}

aBusiness momentum is defined as partnering dialog at an advanced stage, sales taking off, proximity to a new external financing round and so on. profitable and then exit. Because of skyrocketing development costs and time-to-market for new products in large indication areas such as diabetes and cardiovascular disease in recent years, the predominant type of successful exit has come from companies producing or promoting orphan drugs or delivery devices. These companies generally realized more successful exits than biopharmaceutical companies because the regulatory requirements for product approval are less stringent and faster and their market exclusivity longer.

The hard truth, though, is that the ideal time to exit always depends on the particular situation, and generally you will be required to have some sort of proof of concept before you can consider a trade sale. Beyond proof of concept, valuation multiples tend to be closely linked to the development phase of the companies. Those that have achieved proof of business, profitability, or possibly even market leadership achieve higher valuations than those with only proof of concept. Moreover, younger companies all over the globe are very much dependent on how strategically important their particular asset is to the buyer to achieve good valuations ${ }^{3}$.

\section{Competition helps}

One way to help your valuation, no matter where you are located, is to build a real or perceived auction dynamic for your product. One of the seminar's attendees, Otello Stampacchia of London-based Omega Funds, commented. "It is critical to create a perception among potential partners and buyers that there is someone else out there who really wants your product. Otherwise, you might get a 'decent' exit, but you will not get a home-run."

Besides having several suitors, a way to achieve that perception of competing forces is building a sustainable company because that gives you the flexibility to either continue business on your own, to out-license your product, to do a trade sale or even an IPO. Those options mean you are not at the mercy of any one particular bidder. Indeed, a recent trade sale involved 20 initial offers, with five being invited to closing negotiations. Still, an IPO was kept open to the very end, with a prospectus filed four days before closing the trade sale. That helped keep up the momentum of the process.

But while it is best to be prepared for all exit opportunities ${ }^{4}$, be aware that doing so can be both expensive and time consuming. For example, when referring to a recent exit, Stockholm-based investor Thomas Eklund noted, "In hindsight, preparing for an IPO was not worthwhile, given all the money and time it required. But then again, selling this company in Europe was quite simple since the story was well known. If it had ended up in the US, the value of IPO preparations might have been different."

\section{Get out there}

Measured against other industries, VCs and their portfolio companies actually spend relatively little resources on selling their companies (their 'products', in this case) compared with how much they invest in sourcing and developing them. That begs the question: Are venture-backed life science companies spending too little time and money on the exit process?

Perhaps. One way to fight against this is to redefine what 'business development' is at your company. It should mean being 'out there' all the time-in other words, understanding where the big market players are heading, where medical practice is going, what happens at the industry meetings and who key opinion leaders are. You should also know who makes decisions about what assets are to be acquired by the industry. It is not enough to hire the best business developer you can find, and let him or her do their job. As a CEO, or otherwise a member of the executive team, you need to be aware of these issues yourself. In general, skilled senior management with extensive international networks and repeated experience with building companies has proven much harder to find in Europe than in the US. In a trade sale-dominated exit environment, companies that are able to put themselves on the strategic agendas of as many potential buyers as possible have the largest chance of success. Not only do managements need to be committed to business development to achieve this, they must start their business development activities at an early stage. If you are in Europe, you need to visit the US and define your potential buyers. Spend the time to engage the decision makers at the companies that might purchase you. You cannot call up potential buyers the moment you want to sell and expect to get results.

Another tip: use investment bankers to assist you. That doesn't mean you won't have to identify the buyers and attract their interestyou will-but you cannot manage the whole process yourself. Besides, advisors tend to add value to the final price.

\section{Align the syndicate}

You will also need a consensus on your exit strategy with the syndicate of investors. If you have some investors in love with the science, but others backing out, you will be in trouble. Or, when investors come in at differing times, the board of directors might lose control of where the company is going.

Both might prove disastrous when planning for an exit. It is possible that management is conducting business as usual, which might not be what is best to achieve an optimal exit. That such issues arise, however, seems more like the norm than the exception because VCs tend to change priorities over time. What was a perfectly aligned syndicate six months ago might not be so today.

If your syndicate fractures, you will need a plan (Table 1). Be prepared to put a lot of time and effort into it. VCs know that syndicates likely will change, and therefore engage all involved parties in a discussion on exit before making the investment. This allows them to check if there is a fundamental alignment of interest before investment happens.

There are other issues of misalignment of management and boards, and in particular there is often conflict when shifting from a scientifically oriented leadership typical for startup companies to an industrially oriented management ${ }^{5}$. Mainly, this happens because entrepreneurs are characterized by curiosity, creativity, exploration, improvisation and energy. The industry side of things brings 
structure, regulation, standardization, documentation, validation, legislation and commercialization. An entrepreneur often needs to be forced into a pre-defined, squared shape as the company grows.

Our seminar participants warned about the dangers of attempting to force an exit strategy on a scientifically focused management. Ultimately, management will do what it believes in, and if that is not aligned with the board, you will have a major issue to resolve.

\section{US presence}

Whereas it is clear that proof of concept and proof of business are important for life science startups to be attractive targets, to what degree must European companies be approved and present in the United States to be attractive to US buyers? The answer varies.

Sometimes, establishing a foothold in the home market is enough. One attendee at the symposium, former NeoPharma CEO Ulf Rosen, stated, "Our focus was to achieve a relatively high level of penetration on a small number of clinics in our home market. Then, in discussions with international buyers, we argued that if we could reach $8 \%$ penetration with our resources, a global organization should at least be able to do the same on the world market. In North America alone, this corresponds to $\$ 150$ million in revenues."

You might also move your headquarters to the United States a few years before selling, while perhaps keeping clinical operations in the home country. The US team can focus on further development of the product and start preparations for an IPO with US investment banks, if needed. The idea would be to show that the product can be sold in Europe, and thus it's easy for US buyers to extrapolate that into their market. After all, medical practice in the US and Europe is more or less the same.

Although it is true that the United States dominates the transaction market, in principle geographical localization should not mattera great product is great no matter where it is based. Even so, European biotech companies tend to interact with certain people in certain places within certain contexts, while in the United States, companies interact with a larger community of potential buyers and key opinion leaders on a much more constant basis. That is a massive competitive advantage that the management in a European startup needs

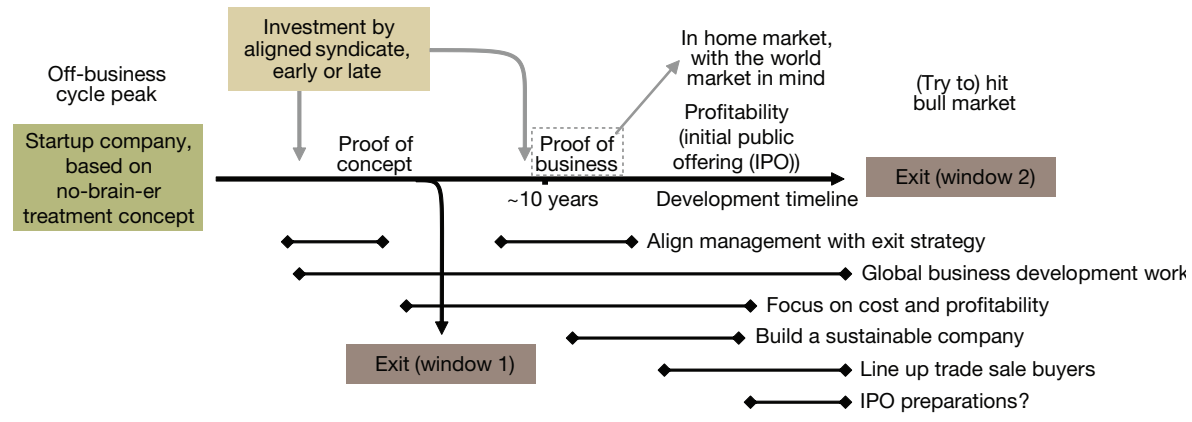

Figure 2 Mapping the path.

to counteract. This can be done by traveling to US events often and also by establishing a very well-connected network of key opinion leaders and scientific advisors. But having their names associated with your company and listed on your website is not enough-you will need to make them visit your company, make them use your products. In other words, make them the best advocate for your product or company.

The uncertainties associated with economic cycles are clearly imperative for venture backed exits, and best practice for exit promotion will need to be moderated for the general economic climate. Going public during a downturn is rarely a viable option and merger and acquisition opportunities will be reduced. Nonetheless, highly successful transactions have taken place in the midst of the recent financial meltdown. The difference there is that those companies were great, not just good. It is very difficult to plan for economic cycles, but if you're planning on exiting when everyone else is, you can consider a higher payout. When transactions are down and the markets shut, certainly expect that to be reflected in your valuations and pricings.

\section{Conclusions}

Successful entrepreneurship in venture backed life science is founded on possessing the science and technology (as well as the adequate legal rights) to fill a clear market need with novel products. However, the level of development costs required to bring many drugs and devices to market limits the investment cases that fit the mandate of many EU venture capital firms. The discussions of successful exits at our seminar focused on either trade sales at an early stage of development or late investments. In particular, the seminar concluded that orphan drugs and devices are a particularly suitable product class for venture investments in Europe.

More than management excellence, scientific foundation and marketability, our seminar pointed out that a competitive sentiment among buyers is a necessary value driver to obtain premium returns from life science exits. Many factors come into play achieving this, such as the early initiation of extensive and international business development efforts directed toward exit, the ability to build a sustainable company and the alignment of investors and management on exit strategy. International business development activities were identified to be of particular importance for European companies. On the contrary, achieving regulatory approval and established business outside domestic markets were not preemptory for successful exits, with the exception of companies striving to achieve revenue based exits or reach the public markets (Fig. 2).

1. Ghalbouni, J. \& Rouziès, D. Harvard Business Review 18, 21-23 (2010).

2. Kaitin, K.I. (ed). The Tufts CSDD Outlook 2010 (Tufts Center for the Study of Drug Development, Medford, MA, 2010).

3. Stewart, J.J. \& Bonifant B. Nat. Biotechnol. 28, 178 (2010)

4. Buckel, P., Dauer, U., Frei, P. \& Nothias, J. Nat. Biotechnol. 25, 1195-1197 (2006)

5. De Rubertis, F., Fleck, R. \& Lanthaler, W. Nat. Biotechnol. 27, 595-597 (2009).
To discuss the contents of this article, join the Bioentrepreneur forum on Nature Network: http://network.nature.com/groups/bioentrepreneur/forum/topics 